\title{
TRAGÉDIA HISTÓRICA E DRAMA ROMÂNTICO
}

\author{
Historical tragedy and romantic drama
}

\author{
Gabriel Esteves \\ https://orcid.org/0000-0003-4719-6672 (0) \\ Universidade Federal de Santa Catarina, Programa de Pós-Graduação em \\ Literatura, Florianópolis, SC, Brasil. 88040-970 - ppglitufsc@gmail.com
}

\begin{abstract}
Resumo: O objetivo deste artigo é recuperar a tragédia histórica como gênero reconhecidamente romântico, quer dizer, como gênero que atende às expectativas de intelectuais identificados com o romantismo nas primeiras décadas do século XIX (Staël, Manzoni, Schlegel, Stendhal, Lebrun, Delavigne etc.), que antecipa e compartilha várias características com o drama (mistura de gêneros, desrespeito às unidades clássicas, realismo histórico, enriquecimento de decoração e figurino, complexificação da trama etc.) e, enfim, que mantém um evidente comércio com o drama e o melodrama durante todo o século, não raro com eles dividindo os mesmos palcos e atores. Para tanto, recorro à análise da recepção jornalística feita à peça Le Cid d'Andalousie, de Pierre Lebrun, encenada em 1825, e argumento contra a concepção amplamente difundida de que o teatro romântico se identifica exclusivamente com o drama tal qual proposto por Victor Hugo, em 1827, no célebre prefácio ao Cromwell, e que a tragédia pertence apenas à tradição clássica.
\end{abstract}

Palavras-chave: Romantismo. Teatro. Tragédia. Drama. Século XIX.

\begin{abstract}
The aim of this article is to recover the historical tragedy as a recognized romantic genre, i.e., as a genre that meets the expectations of intellectuals identified with romanticism in the first decades of the 19th century (Staël, Manzoni, Schlegel, Stendhal, Lebrun, Delavigne etc.), anticipates and shares several characteristics with the romantic drama (mixture of genres, disrespect for classic units, historical realism, enrichment of decoration and costumes, complexification of plot, etc.) and, finally, as a genre that maintains a noticeable relation with both drama and melodrama throughout the century, often sharing the same stages and actors with them. In order to achieve this objective, I study the journalistic reception to the play Le Cid d'Andalousie, by Pierre Lebrun, staged in 1825, and I contest the widespread conception that the romantic theater can be exclusively identified with the drama as proposed by Victor Hugo, in 1827, in the preface to Cromwell, and that the tragedy belongs only to classical tradition.
\end{abstract}

Keywords: Romanticism. Theatre. Tragedy. Drama. 19th century.

\section{Introdução}

Não é raro encontrar manuais de história literária e críticas especializadas que associem o teatro romântico exclusivamente ao gênero que Victor Hugo, no prefácio do Cromwell (1827), chamou de drama romântico. O drama, no entanto, gênero multiforme, volátil, não nasceu pronto da imaginação de um Hugo ou de um Dumas, e hoje é preciso reconhecer que os melodramas e as tragédias históricas (ou românticas) são seus precursores e concorrentes imediatos. "Quand le drame romantique naîtra vers 1828", escreve Ferdinand Brunetière (1902, p. 66), "il n'apportera scéniquement rien de nouveau ; 
il empruntera un peu à la tragédie historique et beaucoup au mélodrame"1. Ou ainda, nas palavras de Jules Marsan (1910, p. 31): "le mélodrame d'une part, les scènes historiques de l'autre : toute la matière du drame nouveau est déjà là, avant Cromwell et Henri III"2. Mas esclareçamos desde já: uma coisa é reconhecer melodramas e tragédias históricas como precursores do drama romântico sem classificá-los propriamente como peças românticas (é o conveniente discurso da literatura de "transição", limbo ${ }^{3}$ entre os sistemas bem definidos, e cujo valor para a crítica é quase nulo). Outra coisa é reconhecê-los como precursores e como gêneros legitimamente românticos, objetando que os dramas de Hugo, Dumas, Vigny et alii encarnem o "verdadeiro" teatro romântico. Trata-se, evidentemente, de um problema de referência historiográfica: se Hugo e Dumas são alçados a modelos arquetípicos do teatro romântico, então todos os autores anteriores a eles serão tomados por precursores em transição, a caminho do sistema referencial ${ }^{4}$, enquanto os autores contemporâneos e posteriores serão interpretados à sua luz. Esse procedimento, aplicado ao teatro romântico, tende a restringir os historiadores da literatura a parâmetros muito estreitos, para não dizer falsos ${ }^{5}$, e é contra ele que proponho este trabalho. Nas próximas páginas, mostrarei que a tragédia histórica atende às expectativas dos intelectuais que se identificavam com o romantismo nas primeiras décadas do século XIX e, não raro, se confunde com o próprio drama.

\section{O gênero romântico antes do Cromwell}

Quem abre o Racine et Shakespeare (1823-1825) de Stendhal, uma das mais significativas reflexões sobre o teatro romântico produzidas na primeira metade do século

\footnotetext{
1 Todas as traduções neste artigo são de minha autoria. "Quando o drama romântico nasce, mais ou menos em 1828, ele não traz, cenicamente, nada de novo. Ele toma um pouco de empréstimo à tragédia histórica e muito ao melodrama".

2 "O melodrama de um lado, as cenas históricas do outro: toda o material do novo drama já está aí, antes do Cromwell e do Henri III".

${ }^{3}$ Este é o termo que Antonio Candido (2000) escolhe para se referir ao conjunto dos poetas brasileiros que escreveram no início do século XIX: "conjunto não raro contraditório, de classificação difícil - verdadeiro limbo poético onde o fim é o começo, o começo é o fim, a mediocridade universal, com a exceção, não de autor, mas de uma ou outra peça" (2000, p. 284).

${ }^{4}$ É bastante ilustrativo desse modo de conceber a história literária a maneira como Gustave Lanson (1911), em seu Manuel bibliographique de la littérature française moderne, dispõe a bibliografia de autores como Alexandre Soumet, Pierre Lebrun, Cavet e Dittmer na sessão La préparation du Drame Romantique (para não falar de Casimir Delavigne, abandonado ao fin de la tragédie classique), reservando a sessão Le théâtre des grands romantiques essencialmente para Hugo, Vigny, Musset e Dumas. Cf. LANSON, 1911.

${ }^{5}$ No Brasil, o teatro romântico, sobretudo para os historiadores do século XX, costuma ser definido, de maneira muito superficial, pela prosa (no lugar do verso), pelo rompimento das unidades aristotélicas, pelo desrespeito aos 5 atos tradicionais e pelo drama (no lugar da tragédia). Veja-se, por exemplo, o julgamento que Alfredo Bosi (1975) faz em relação à tragédia Antônio José (1839), de Gonçalves de Magalhães, ou a comparação que José Veríssimo faz entre Garrett e o mesmo Magalhães no capítulo IX da sua História da literatura brasileira (1916). Se nos ativermos apenas a essas regras sumárias, haveremos de convir que o Hernani (1830) de Victor Hugo, com seus cinco atos em verso, não é uma peça perfeitamente romântica, e que a tragédia Caligula (1838 [encenada em 1837]), de Dumas, a despeito de toda a sua mise en scène melodramática e do seu preciosismo histórico, não passa de um fruto do classicismo.
} 
$\mathrm{XIX}^{6}$ - ironicamente por um homem que "n'est romantique en rien, si ce n'est pour le théâtre" (TIEGHEM, 1923, p. 148) ${ }^{7}$-, se surpreende com o vocabulário de um autor que fala todo o tempo em tragédie nouvelle e tragédie romantique. O romantismo aplicado ao gênero trágico [genre tragique], ele diz, "c'est une tragédie en prose qui dure plusieurs mois et se passe en divers lieux" (STENDHAL, 1854, p. 178) ${ }^{8}$. Em dado momento da sua argumentação, mencionando um diálogo travado com um homme à argent do teatro, Stendhal chega mesmo a misturar os termos drame romantique e tragédie, mostrando que, dentro do seu vocabulário, eles são sinônimos:

Auquel de nos théâtres conseilleriez-vous de monter un drame romantique en cinq actes et en prose intitulé La Mort du duc de Guise à Blois, ou Jeanne d'Arc et les Anglais, ou Clovis et les évêques ? Sur quel théâtre une telle tragédie pourrait-elle arriver au troisième acte ? (STENDHAL, 1854, p. 199, grifos meus) ${ }^{9}$

É 1825, plena alvorada do romantismo francês. Podemos nos escandalizar com essa confusão de termos? Não; na verdade, ela era corriqueira - como ainda hoje, a palavra "drama", em sua acepção genérica, servia para indicar qualquer obra teatral, a despeito do gênero em que se alistasse. Como explicar, por outro lado, que as discussões em torno do teatro romântico ainda se dessem, em 1825, nos termos da tragédia? ${ }^{10}$ Comecemos essa investigação passando à Itália - ou melhor, a Milão, de onde Stendhal, que lá esteve em 1816, parece ter tirado algumas de suas convicções dramáticas ${ }^{11}$.

Em 1827, no ano em que Victor Hugo parafraseou algumas ideias do Cours de littérature dramatique de August Schlegel (traduzido em 1814 para o francês), sobretudo tiradas da lição número 13, e publicou o seu Cromwell, o projeto de uma literatura assumidamente romântica e de um teatro nacional já vinha sendo discutido há mais de década na Itália, sobretudo pelos escritores do curtíssimo mas prolífico jornal milanês /I

\footnotetext{
${ }^{6}$ Apesar do peso que hoje atribuímos a esse trabalho, Brunetière (1902) pensa que não devemos exagerar a sua influência na época: "il ne faudrait pas exagérer l'influence de Stendhal, qui fut, en réalité, presque nulle" (1902, p. 41). Em minha tradução: "não se poderia exagerar a influência de Stendhal que, na verdade, foi quase nula".

7 "Não é romântico em nada, a não ser pelo teatro".

8 "É uma tragédia em prosa, que dura vários meses e se passa em vários lugares".

9 "A qual dos nossos teatros você aconselharia a montar um drama romântico em cinco atos e em prosa intitulado A Morte do duque de Guise em Blois ou Joana d'Arc e os Ingleses, ou Clóvis e os bispos? Em qual teatro uma tal tragédia poderia chegar ao terceiro ato?".

10 Stendhal (1908), mesmo em 1830, chamaria o Hernani de "tragédie M. Victor Hugo, mal imitée des 2 gentlemen of Verona et autres pièces de ce genre du divin Shak[espeare]" (1908, p. 520-521). Em minha tradução: "tragédia do senhor Victor Hugo, mal imitada do 2 Gentlemen of Verona e outras peças desse gênero do divino Shakespeare".

11 Stendhal era amigo dos jovens por trás do Conciliatore, de que falarei logo em seguida, inclusive de Ludovico di Breme, um dos idealizadores do periódico e frequentador do salão de Staël no castelo de Coppet, por quem teria sido recentemente convertido "aux idées romantiques de nuance allemande" (TIEGHEM, 1948, p. 198) - em minha tradução: "às ideias românticas de nuance alemã". Assim dizia Stendhal, no dia 12 de novembro de 1816, em Rome, Naples et Florence: "Je vais tous les jours dans la loge de M. de Brème à la Scala. C'est une société toute littéraire" (STENDHAL, 1919, p. 70). Em minha tradução: "eu vou todos os dias ao camarote do senhor de Breme, no La Scala [teatro de Milão]. Trata-se de uma sociedade literária”, e segue listando os participantes do grupo.
} 
Conciliatore (1818-1819) - "nulle part", escreve Jules Marsan (1910, p. 6), "le problème du drame historique $\mathrm{n}$ s'est posé plus nettement"12. Essas discussões, contudo, sempre se davam nos termos da tragédia: "ils se contentent d'ailleurs de l'expression tragédie romantique" (TIEGHEM, 1948, p. 200) ${ }^{13}$. Movido pela efervescência do contexto e com a clara intenção de fazer algo novo pelo teatro italiano ${ }^{14}$, Alessandro Manzoni, "buon genio tutolare dei nostri primi romantici" (CLERICl, 1903, p. 73) ${ }^{15}$, publicou II Conte di Carmagnola em 1820, tragédia em cinco atos, completamente versificada. A sua peça foi prontamente traduzida para o francês e discutida com interesse pela Europa. Tal foi o seu sucesso que o próprio Goethe, a maior autoridade literária da época, se viu obrigado a dedicar-lhe um minucioso estudo na revista Über Kunst und Altertum, depois republicado como anexo na versão impressa da tragédia. O que o Conte di Carmagnola tinha de fundamentalmente novo, mas nem tão novo assim ${ }^{16}$, era a desatenção proposital a duas regras clássicas da composição trágica que haviam sido recentemente contestadas por August Schlegel e Germaine de Staël: as unidades de tempo e lugar. Por outro lado, a despeito dessas intenções românticas, Manzoni continua ocupado com tragédias, sem associar o termo à antiguidade, e fala em "drama" apenas no sentido genérico da palavra. Na prefazione do Conte di Carmagnola, por exemplo, ele se opõe às regras do drama e da tragédia ${ }^{17}$ indistintamente; naquela famosa Lettre à $M$. C. sur l'unité de temps et de lieu dans la tragédie, a mesma coisa: ora fala nas unidades da tragédia (como no próprio título), ora na "question des unités dans le drame" $(1834, \text { p. } 398)^{18}$, exatamente como faziam os colaboradores do Conciliatore. Claude Fauriel, no prefácio que escreveu para a sua tradução, fala em "système de la tragédie historique, tel que le conçoit $\mathrm{M}$. Manzoni" (FAURIEL, 1834, p. XVI) ${ }^{19}$, e lembra que o próprio poeta permitia que esse sistema fosse

12 "Em nenhum lugar [além da Itália] o problema do drama romântico se colocou de maneira mais clara".

13 "Eles se contentavam com a expressão tragédia romântica".

${ }^{14} \mathrm{Em}$ carta de 1816 a Claude Fauriel, seu amigo e tradutor francês, Manzoni dizia: “j'ai presque honte [...] de vous parler de projets littéraires après en avoir tant conçu et exécuté si peu, mais cette fois j'espère terminer une tragédie [...] que j'ai commencée avec beaucoup d'ardeur et l'espoir de faire au moins une chose neuve chez nous" (MANZONI apud WAILLE, 1890, p. 134). Em minha tradução: "eu tenho quase vergonha de lhe falar em projetos literários depois de haver concebido tantos e executado tão poucos, mas desta vez eu espero terminar uma tragédia que comecei com muito ardor e esperança de fazer pelo menos uma coisa nova em nossa terra".

15 "Bom gênio tutelar dos nossos primeiros românticos", ou seja, os jovens do Conciliatore.

${ }_{16} \mathrm{Um}$ leitor italiano familiarizado com as discussões do seu tempo, segundo Luigi Ferrari (1900), não veria novidade teórica no Conte di Carmagnola: "la legge delle due unità, di luongo e di tempo, che la Biblioteca italiana, nel 1817, affermava essere la cagione principale della discordia fra romantici e classici, era stata sconfessata più volte da critici italiani nel '700: dal Becelli, dal Baretti, dal Metastasio, dal Buonafede e dal Carli" (FERRARI, 1900, p. 97). Em minha tradução: "a lei das duas unidades de lugar e tempo que a Biblioteca italiana, em 1817, afirmava ser a principal causa da discórdia entre românticos e clássicos, tinha sido renegada várias vezes por críticos italianos do século XVIII: por Becelli, por Baretti, por Metastasio, por Buonafede e por Carli". Quanto ao uso artificial do paganismo e sua crítica já no século XVIII, na Itália, vejase o mesmo livro de Luigi Ferrari, Del "Caffè" (1900, p. 98-100).

17 Vale notar que Manzoni escreve "tragedie inglesi e tedesche" (1826, p. 11) - "tragédias inglesas e alemãs" -, exatamente como Madame de Staël (1813, p. 17) escreve "tragédies anglaises ou allemandes".

18 "Questão das unidades no drama".

19 "Sistema da tragédia histórica, tal qual o concebe o senhor Manzoni". O próprio poeta, na Lettre à M. C. sur l'unité de temps et de lieu dans la tragédie, diz que é preciso investigar as "tragédies conçues dans le système historique" (1834, p. 421) - em minha tradução: "tragédias concebidas no sistema histórico". Vale lembrar 
rotulado como romântico 20 :

Que si l'on voulait désigner par un nom d'école l'ensemble des idées de M. Manzoni sur la théorie de la tragédie, et donner à cette théorie le titre de romantique, on y serait autorisé par $\mathrm{M}$. Manzoni lui-même, qui ne rejette pas ce titre. (FAURIEL, 1834, p. IV) ${ }^{21}$

A princípio, portanto, vemos que as discussões relativas ao teatro romântico se dão nos termos da tragédia e, especialmente no universo novilatino, nos termos da tragédie historique. Foi essa a expressão preferida por Germaine de Staël para se referir ao gênero que, ela pensava, deveria representar a nova escola nos palcos: "ce que j'ai déjà dit sur la poésie classique et romantique s'applique aussi aux pièces de théâtre. Les tragédies puisées dans la mythologie sont d'une toute autre nature que les tragédies historiques" (STAËL-HOLSTEIN, 1813, p. 5) 22. Tragédias históricas são, portanto, em oposição às tragédias de inspiração mitológica, românticas. Apesar da longa convivência com August Schlegel, Staël não fala uma só vez em drame romantique no célebre De l'Allemagne, e mesmo Schlegel parece usar essa expressão de modo muito vago, como quem sente a falta de um termo mais apropriado - além de drame romantique, ele também se refere a essas produções, segundo pude observar, como genre romantique, pièces de théâtre romantiques, pièces romantiques, tragédie historique e tragédie romantique. Essa última expressão, Schlegel utiliza apenas uma vez na página 524 do terceiro tomo da edição referida na bibliografia, claramente como sinônimo de tragédie historique ${ }^{23}$. Também Simonde de Sismondi, outro frequentador do salão da Madame de Staël, fala indistintamente de tragédie romantique e drame romantique em De la littérature du midi de l'Europe (1813). O termo tragédie romantique, Germaine de Staël o utiliza apenas uma vez

ainda que, segundo Paul Van Tieghem (1948, p. 199), "le romantisme italien est appelé par certains de ses adhérents "école historique " - em minha tradução: "o romantismo italiano é chamado por alguns de seus participantes de 'escola histórica”".

20 Fauriel (1834) também ressalta, por outro lado, que Manzoni tem uma concepção especial do termo "romantismo", distinta de todas as outras adotadas até então e pouca dada a exclusivismos de escola: "la vérité est que les doctrines poétiques de M. Manzoni sont trop indépendantes, trop élevées, tiennent de trop près à tout ce qu'il y a de raisonnable et de démontré dans les divers systèmes littéraires, pour qu'une dénomination exclusive puisse leur convenir" (FAURIEL, 1834, p. IV) - em minha tradução: "a verdade é que as doutrinas poéticas de Manzoni são independentes demais, elevadas demais, se aproximam de tudo o que há de razoável e demonstrado nos diversos sistemas literários para que uma denominação exclusiva possa convir a elas". O romantismo de Manzoni, portanto, não representa uma recusa dogmática do universo clássico. Não seria de todo inútil lembrar, aliás, que Manzoni trata a querela clássico-romântica como um evento já superado na Lettera al marchese Cesare d'Azeglio, de 1823, do qual seria possível extrair lições para o desenvolvimento de uma literatura futura, mas sem ressuscitar o confuso epíteto "romântico": "sarebbe un rinnovare la guerra, e forse un far danno all'idea che, senza nome, vive e cresce con bastante tranquillità" (MANZONI, 1881, p. 597), em minha tradução: "seria renovar a guerra e talvez danificar a ideia que, sem nome, vive e cresce com bastante tranquilidade".

21 "Se se quisesse designar por um nome de escola o conjunto das ideias do senhor Manzoni sobre a teoria da tragédia e dar a essa teoria o título de romântica, o próprio senhor Manzoni, que não rejeita esse título, o autorizaria".

22 "O que eu já disse sobre a poesia clássica e romântica se aplica também às peças de teatro. As tragédias extraídas da mitologia são de uma natureza completamente diferente das tragédias históricas".

${ }^{23}$ Aqui faço menção à tradução francesa de 1814 que, segundo a nota introdutória, é a única que o próprio August Schlegel considerava autêntica e pela qual gostaria de ser julgado. 
em De l'Allemagne (1813, p. 113) para se referir à Jeanne d'Arc de Schiller, pois foi assim que o autor a chamou: romantische Tragödie. Essa expressão, no entanto, ganhou seus adeptos: ela foi frequentemente empregada pelos românticos milaneses, por Stendhal em Racine et Shakespeare (como vimos), e parece mesmo ter chegado à Rússia ${ }^{24}$.

Madame de Staël tinha tão forte convicção de que a tragédia histórica prosperaria no século XIX que arriscou uma profecia: "la tendance naturelle du siècle c'est la tragédie historique" (STAËL-HOLSTEIN, 1813, p. 17), quer dizer, a tendência natural do século é a tragédia histórica. Adepto do mesmo credo, Benjamin Constant fez eco ao presságio num artigo de 1817, publicado no Mercure de France:

D'après nos institutions actuelles, il me paraît certain que nos poètes seront poussés presque exclusivement vers la tragédie historique ; et, dans la tragédie historique, il sera difficile de ne pas admettre au moins en partie le système des étrangers. (CONSTANT, 1817, p. 490) ${ }^{25}$

Parece que acertaram. No início do século XIX, um interesse pujante pelo passado, notadamente o medieval, varou bibliotecas, livrarias e salões ocupados pela intelligentsia francesa, inspirando poetas e eruditos a combinarem duas grandes paixões: o drama e a história. Queria-se, sobretudo, com essas produções romântico-históricas, duas coisas: tragédias inspiradas em eventos históricos (nisso também vai inserido o preciosismo quanto à decoração, os modos, as vestimentas, as palavras etc.) e o afrouxamento das regras clássicas (a mistura dos gêneros e dos contrários aqui também inserida). Essas duas demandas se interdependem: o desejo de levar grandes eventos históricos aos palcos é inevitavelmente seguido pelo desejo de afrouxar as regras clássicas. É nesse contexto em que historicismo e romantismo se confundem que o desenvolvimento da nova tragédia histórica se vê favorecido 26 :

La tragédie historique empruntée, non plus aux souvenirs de l'antiquité

\footnotetext{
${ }^{24} \mathrm{O}$ jovem Pushkin a emprega para se referir à peça que escrevia em 1825. Sobre o uso da expressão "tragédia romântica", veja-se o livro The Letters of Alexander Pushkin (1967), organizado por Thomas Shaw, nas páginas 229 e 261; sobre as ideias francamente românticas que Pushkin nutria a respeito do teatro, ver as páginas 237 e 367 do mesmo livro.

25 "Segundo nossas instituições atuais, me parece certo que os nossos poetas serão atraídos quase exclusivamente pela tragédia histórica, e nela será difícil não admitir, pelo menos em parte, o sistema dos estrangeiros [refere-se aos alemães e ingleses, sobretudo]".

26 Às tragédias românticas poderiam ser ajuntadas as cenas históricas, cuja influência sobre o drama romântico não foi nada desprezível. Alexandre Dumas, por exemplo, no prefácio ao drama Henri III et sa cour (1829), escreve que Mérimée, Vitet, Loëve-Weimar, Cavé e Dittmer são, ao lado de Victor Hugo, os fundadores do gênero a que se lançava: "je ne me déclarerai pas fondateur d'un genre, parce qu'effectivement je n'ai rien fondé. MM. Victor Hugo, Mérimée, Vitet, Loëve-Weimar, Cavé et Dittmer ont fondé avant moi, et mieux que moi; je les en remercie; ils m'ont fait ce que je suis" (DUMAS, 1829, p. VII), em minha tradução: "eu não me declararei fundador de um gênero, porque, com efeito, eu não fundei nada. Os senhores Victor Hugo, Mérimée, Vitet, Loëve-Weimar, Cavé e Dittmer o fundaram antes e melhor do que eu. Eu os agradeço; eles me fizeram isso que eu sou". O estudo dessas obras, no entanto, mais destinadas à leitura atenta do que à representação nos palcos, mais preocupadas com a precisão histórica do que com o movimento das cenas, reclama um espaço à parte. Ao leitor interessado nesse outro teatro romântico, antes ligado ao prosaísmo de Stendhal do que ao lirismo de Hugo, me limito a recomendar o artigo de Jules Marsan mencionado na bibliografia deste trabalho, Le théâtre historique et le romantisme (1910).
} 
classique, mais à l'histoire moderne ou nationale, c'est là ce qu'avaient réclamé Benjamin Constant, Mme de Staël, Schlegel, Manzoni. Or à ce moment se produisait sous l'influence de Chateaubriand un véritable éveil des études historiques ; Augustin Thierry et Marchangy faisaient renaître la France moyenâgeuse ; Thiers, Mignet et Michelet s'adonnaient à I'histoire moderne. En outre le développement considérable du roman historique à l'imitation de Walter Scott, et les traductions des dramaturges allemands, dont le théâtre abondait précisément en pièces historiques, tout cela ne pouvait que favoriser cette tendance nouvelle des esprits. (BRUNETIĖRE, 1902 , p. 66$)^{27}$

Brunetière hesita em classificar essa nova tragédia como romântica - ele a chama "genre intermédiaire" (1902, p. 65) ${ }^{28}$-, mas todas as evidências sugerem, ao contrário, que ela foi uma das principais manifestações do teatro romântico antes do drama hugoano, pois correspondia precisamente aos anseios dos primeiros teóricos e entusiastas do romantismo francês. O Globe, por exemplo, esse jornal de liberais e francos apoiadores da reforma dramática (e que chegam a descrevê-la, às vezes, como uma verdadeira destituição do monopólio estatal representado pela tragédia clássica ${ }^{29}$ ), ainda publicava, como Stendhal, um artigo favorável à tragédia histórica em 1825:

La tragédie historique et libre n'est pas à coup sûr le romantisme tout entier: mais elle en est l'une des branches les plus importantes, celle peut-être vers laquelle la direction actuelle des esprits nous pousse le plus irrésistiblement, celle qui nous promet les jouissances les plus vives. (O., 1825, p. 424)

E o Figaro, dois anos mais tarde, em 1827, equiparava tragédie romantique e drame historique, completamente alheio à cisão que se operaria daí a dois meses:

Le théâtre s'est vu débarrasser des curieux qui l'encombraient et qui ne laissaient à Oreste que dix pieds carrés pour se débattre contre les sœurs infernales ; les décorations et les costumes se sont rapprochés de la vérité. Puisque tous les moyens physiques d'exécution ont été perfectionnés, le moule usé dans lequel on jette depuis deux siècles la tragédie doit aussi être remplacé. Au lieu de ces conversations interminables, de ces lieux communs de rhétorique et de philosophie qui font la base de la tragédie classique, le poète peut maintenant nous montrer de grands tableaux d'histoire,

\footnotetext{
27 "A tragédia histórica, emprestada não mais às lembranças da antiguidade clássica, mas à história moderna ou nacional: é isso o que haviam reclamado Benjamin Constant, Madame de Staël, Schlegel, Manzoni. Nesse momento se produzia, sob a influência de Chateaubriand, um verdadeiro despertar dos estudos históricos. Augustin Thierry e Marchangy faziam renascer a França medieval; Thiers, Mignet e Michelet se dedicavam à história moderna. Além disso, o desenvolvimento considerável do romance histórico à imitação de Walter Scott e as traduções dos dramaturgos alemães, cujo teatro abundava precisamente em peças históricas, tudo isso só podia favorecer essa tendência nova dos espíritos".

28 "Gênero intermediário".

29 Leia-se, por exemplo, o artigo De l'independence en matière de goût, publicado pelo Globe em 23 de abril de 1825, que aponta os malefícios da intervenção governamental no teatro e chega a falar em "compagnies de capitalistes" que "si proposent d'exploiter le romantisme", quer dizer, companhias de capitalistas que se propõem a explorar o romantismo, mas não podem fazê-lo, porque o monopólio do classicismo segue reinando.

30 "A tragédia histórica e livre não é certamente todo o romantismo, mas ela é um dos seus ramos mais importantes, talvez esse para o qual a direção atual dos espíritos nos impele mais irresistivelmente, esse que nos promete os prazeres mais vivos".
} 
embrasser un large horizon, faire mouvoir des ressorts plus puissants. Telle sera la tragédie romantique que l'on appellera, si l'on veut, drame historique par respect pour Aristote qui ne s'en embarrasse guère. (DU DRAME HISTORIQUE ET DE LA TRAGÉDIE ROMANTIQUE, 1827, p. 433, grifos meus) ${ }^{31}$

Ora, convenhamos: deve haver algo de romântico nessas tragédias históricas, apesar do que dizem os adeptos do maniqueísmo trágico-dramático. A essa altura, convém que eu sustente meu argumento com um exemplo. Voltemo-nos, então, para um caso paradigmático da tragédia romântica: Le Cid d'Andalousie, de Pierre Lebrun, encenada no dia primeiro de março de 1825, na Comédie-Française.

\section{O Cid de Lebrun}

Comecemos propondo algumas perguntas que revelam semelhanças entre a peça de Lebrun e o que viria, poucos anos mais tarde, a ser estritamente associado ao drama:

Qu'était-ce donc que cette prétendue tragédie, où des scènes interminables, scènes épisodiques s'il en fut, entravaient sans cesse la marche de l'action, où les règles n'étaient pas observées, où abondaient, enfin, les trivialités de langage ? (GROS, 1924, p. 12) $)^{32}$

É assim que Etienne Gros, num artigo sobre a reutilização do Cid de Corneille no século XIX, nos introduz a essa tragédia cujas indicações minuciosas de mise en scène "font penser, dès 1823, à certains drames romantiques"33, e cujo método seria logo adaptado pelos protagonistas do Cénacle: "les Romantiques, Hugo en tête, ne feront que reprendre, préciser et amplifier le procédé de Lebrun” (1924, p. 14) ${ }^{34}$. Gros chega mesmo a escrever, em referência às duras censuras impostas ao texto do Cid d'Andalousie e à má recepção no Théâtre-Français, que a primeira representação da tragédia "eut des allures de bataille", como se fosse "une escarmouche avant Hernani" (1924, p. 12) ${ }^{35}$, mas nenhuma dessas evidências (e outras virão se somar a elas) é bastante para convencê-lo de que o Cid de Lebrun é romântico. Cioso de uma explicação para esse romantismo anterior ao Cromwell, Gros recorre ao cabedal da historiografia francesa e de lá retira a magra

\footnotetext{
31 "O teatro se viu desembaraçado dos curiosos que lhe encobriam e que não deixavam a Orestes mais que dez pés quadrados para se debater contra as irmãs infernais; as decorações e as fantasias se aproximaram da verdade. Pois que todos os meios físicos de execução foram aperfeiçoados, o molde usado no qual se representa há dois séculos a tragédia deve também ser substituído. No lugar dessas conversações intermináveis, desses lugares comuns de retórica e de filosofia que fazem a base da tragédia clássica, o poeta pode agora nos mostrar grandes quadros da história, abraçar um largo horizonte, mover as molas mais poderosas. Tal será a tragédia romântica que se chamará, se se quiser, drama histórico (por respeito a Aristóteles que não se incomoda muito)".

32 "O que foi essa pretensa tragédia onde cenas intermináveis, cenas episódicas (se as houve), atrapalhavam incessantemente a o andamento da ação, onde as regras não foram observadas, onde abundavam, enfim, as trivialidades de linguagem?".

33 "Fazem pensar, desde 1823 [ano em que a peça foi escrita], em certos dramas românticos".

34 "Os românticos, com Hugo à frente, não farão nada mais que retomar, precisar e amplificar o processo de Lebrun".

35 Tradução da passagem completa: "a primeira representação teve fumos de batalhas, foi como uma escaramuça antes de Hernani".
} 
expressão "œuvre de transition", que nada significa36:

Le Cid d'Andalousie, comme Marie Stuart, est avant tout, en effet, une œuvre de transition: ce n'est plus une tragédie, ce n'est pas tout à fait un drame, c'est quelque chose d'intermédiaire entre le drame et la tragédie. (GROS, 1924 , p. 13) $)^{37}$

Obra de transição! É semi-romantique (1924, p. 23) a etiqueta que Gros concede ao autor do Cid d'Andalousie, porque pensa, é claro, que apenas o drama pós-Cromwell, e sobretudo aquele ligado ao Cénacle de Hugo, é romântico. Tal é a rigidez, na França (e no Brasil, por extensão), da associação entre drama e romantismo, tragédia e classicismo. É fácil verificar, contudo, se nos debruçamos sobre a recepção crítica da tragédia, que ela foi, em 1825, censurada pelos partidários do classicismo e acolhida pelos românticos que, conscientes da natureza do ataque, tomaram a dianteira e correram em defesa de Lebrun.

Primeiro, a ofensiva: nos dias 3 e 10 de março de 1825, o Journal des débats politiques et littéraires ${ }^{38}$ publicou uma crítica sobre o Cid d'Andalousie. O autor do artigo, identificado apenas como "C.", relata que a tragédia de Lebrun (e ele hesita em chamá-la de tragédia) não obteve êxito no palco precisamente porque desrespeitava regras dramáticas e misturava elementos que não deviam aparecer juntos numa tragédia digna de apreço:

II est difficile d'assigner un genre fixe à un drame mixte qui, dans ses différentes parties, semble appartenir à tous les genres. Le peu de succès qu'il a obtenu, les murmures qu'il a souvent excités prouvent contre tous les fauteurs des hérésies littéraires, que, de la confusion et du mélange bizarre de tous les éléments de l'art dramatique, ne naîtra jamais cet intérêt puissant et victorieux dont l'unique source est à jamais fixée, du moins pour nous, dans la simplicité de l'action, dans l'unité des moyens, et par-dessus tout dans la correction élégante du style. En rapprochant des objets aussi disparates que des courtoisies galantes et des crimes lâches et atroces, les délicatesses du sentiment le plus tendre et les conseils ou plutôt les ordres d'un double assassinat, les pompes domestiques du mariage et la solennité

\footnotetext{
${ }^{36}$ Literalmente, significa nada. Escrevendo sobre La Fille du Cid (1840), tragédia de Casimir Delavigne muito posterior à invenção do drama hugoano (e que sugere, ainda uma vez, que o romantismo não se concentra no drama, mesmo depois de 1830), Etienne Gros (1924, p. 36) diria: “La Fille du Cid n'est plus une tragédie; elle n'a rien de ce qui faisait l'action tragique dans le Cid et ailleurs. Elle n'est pas un drame. A peine pourraiton la ranger parmi ces œuvres hybrides qui, n'étant plus des tragédies, ne sont que "des drames honteux", ou, plus exactement, ne sont rien" - em minha tradução: "La Fille du Cid não é mais uma tragédia; ela não tem nada daquilo que fazia a ação trágico no Cid e alhures. Ela não é um drama. Nós poderíamos com dificuldade arranjá-la entre essas obras híbridas que, não sendo mais tragédias, são apenas 'dramas vergonhosos', ou, mais exatamente, não são nada". A expressão "drame honteux" é provavelmente tirada do Esquisse d'une histoire de la tragédie française (1920), de Gustave Lanson, que assim se refere à outra tragédia de Delavigne, Marino Faliero (1829). Cf. LANSON, 1920, p. 132. Se esse julgamento não demonstra que o monopólio do drama sobre o teatro romântico é nocivo para o estudo e para a justa apreciação da literatura oitocentista, não sei o que o fará.

37 "O Cid d'Andalousie, como Marie Stuart, é, antes de mais nada, com efeito, uma obra de transição: não é mais uma tragédia, não é ainda um drama; é alguma coisa intermediária entre o drama e a tragédia".

38 Em 1820, quando Lebrun publica Marie Stuart, o Journal des débats já o identificava como representante do partido romântico: "la joie est dans le camp des romantiques. Le succès de M. Lebrun est un succès de parti, une victoire des lumières sur les préjugés" (R., 1820, p. 1). Em minha tradução: "a alegria está no campo dos românticos. O sucesso do senhor Lebrun é um sucesso de partido, uma vitória das luzes sobre os preconceitos".
} 
des assises juridiques, on croit multiplier ses ressources et jeter de la variété dans ses compositions; on se trompe. Le contact de la noblesse et de la familiarité donne à l'une le caractère de l'exagération, à l'autre celui de la trivialité et de la bassesse. (C., 1825a, p. 4)

A composição paradoxal das personagens, além do mais, teria prejudicado a interpretação dos atores, pois eles não souberam lidar com os "rôles mi-partis de sérieux et de comique" (C., 1825a, p. 4), quer dizer, com os papéis sério-cômicos propostos por Lebrun. O autor do artigo chama atenção, sobretudo, para a encenação sofrível de Mademoiselle Mars, conhecida na época como grande intérprete de comédias, e que agora se arriscava em papéis sérios:

Rien n'est peut-être plus propre à démontrer la grandeur de l'intervalle qui doit séparer à jamais les deux genres de la scène française que la difficulté qu'éprouve aujourd'hui Mlle. Mars à la franchir. C'est précisément parce qu'elle excelle dans l'un qu'elle a de la peine à arriver à l'autre. (C., 1825b, p. 3$)^{40}$

O autor de um outro artigo publicado a 5 e 6 de março na Gazzete de France seguiu os passos do primeiro e continuou tecendo críticas aos atores em cena:

Talma déploie dans le personnage de don Sanche de la noblesse et de la chaleur sans efforts aux situations qui réclament l'emploi de ces qualités précieuses; mais il est bien lourd et bien marqué dans la comédie. Les déclarations d'amour ne lui ont jamais été favorables. Pour quel motif Talma les risquerait-il sur la fin de sa carrière théâtrale ? Ne forçons point notre talent. (CH., 1825, p. 3, grifos no original) ${ }^{41}$

Tragédia e comédia se confundem: a maior atriz cômica de Paris é atraída pela tragédia; Talma - o lendário Talma! -, ator trágico por excelência, se aventura na comédia e nas declarações de amor (nada, aliás, que ele já não havia feito). Os clássicos não gostaram; quando Talma descalçava os coturnos de Melpômene, "ce n'était plus Talma"

\footnotetext{
39 "É difícil atribuir um gênero fixo a um drama misto que, em suas diferentes partes, parece pertencer a todos os gêneros. O pouco de sucesso que ele obteve, os murmúrios que ele frequentemente excitou provam, contra todos os provocadores de heresias literárias, que da confusão e da mistura bizarra de todos os elementos da arte dramática nunca nascerá esse interesse potente e vitorioso do qual a fonte única está para sempre fixada, ao menos para nós, na simplicidade da ação, na unidade dos meios, e acima de tudo, na correção elegante do estilo. Reunindo objetos tão díspares quanto cortesias galantes e crimes covardes e atrozes, as delicadezas do sentimento mais terno e os conselhos, ou melhor, as ordens de um duplo assassinato, as pompas domésticas do casamento e a solenidade dos fundamentos jurídicos, crê-se multiplicar os seus recursos e ajuntar variedade às suas composições. Engana-se. O contato da nobreza e da familiaridade dá a um o caráter da exageração, ao outro o da trivialidade e da baixeza".

40 "Nada talvez seja mais próprio para demonstrar a grandeza do intervalo que deve separar para sempre os dois gêneros da cena francesa do que a dificuldade experimentada hoje por Mademoiselle Mars para atravessá-lo. É precisamente porque ela se destaca em um gênero que ela tem dificuldades para chegar ao outro".

41 "Talma implanta, no personagem de don Sanche, nobreza e calor sem esforço nas situações que reclamam o emprego dessas qualidades preciosas. Mas ele é bem pesado e bem marcado na comédia. As declarações de amor nunca lhe foram favoráveis. Por que motivo Talma se arriscaria nelas ao fim de sua carreira teatral? Não forcemos nosso talento".
} 
(C., 1825a, p. 4) ${ }^{42}$. Unidos à representação de assassinatos, amores noturnos e nobres falando trivialidades aos olhos da plebe, Talma e Mars, esses dois símbolos da mistura de gêneros promovida pelo Cid d'Andalousie, bem valeram as injúrias recebidas. $\mathrm{O} C \mathrm{C}$. da Gazzete de France, a exemplo do C. do Journal des débats, também nega que o produto dessa barafunda seja chamado de tragédia: "cette pièce", ele escreve, Lebrun a "décore du titre de tragédie", mas "n'appartient réellement à aucun genre connu" $(\mathrm{CH} ., 1825, \text { p. } 3)^{43}$. Ele se engana: a tragédia romântica de Lebrun repousa sobre ponderações bem conhecidas a essa altura, há mais de década apregoadas pelos textos de Staël, Constant, Guizot et alii.

Passemos, agora, à defesa. Ela é representada, sobretudo, por uma crítica publicada no Globe em 3 e 7 de março de 1825, onde o Cid d'Andalousie é logo no título anunciado como tragédie nouvelle, e os seus detratores descritos como "nos adversaires" (THÉÂTREFRANÇAIS, $1825 \mathrm{~b}$, p. 378$)^{44}$. Primeiro, como de praxe, o autor do artigo oferece uma descrição da peça. Ele destaca a originalidade da famosa "cena do banco":

Le jour est à son déclin : la lune vient de se lever ; les suaves parfums de la nuit embaument l'air, et dans le lointain se font entendre les sons mourants de la bruyante joie des fêtes ; ils arrivent jusqu'à l'oreille des deux amants, et c'est alors que commence entre eux une scène sans exemple sur notre théâtre, et d'un charme vraiment inexprimable. (THÉÂTRE-FRANÇAIS, 1825a, p. 374$)^{45}$

"N'est-elle pas comme une première et maladroite ébauche de la scène entre dona Sol et Hernani?"46, se pergunta Etienne Gros (1924, p. 17). De certa forma, sim. Aos críticos de 1825, contudo, que ainda não haviam assistido ao Hernani, essa cena noturna e sentimental fez pensar prontamente no encontro furtivo de Romeu e Julieta (outra referência "romântica" de Lebrun ${ }^{47}$ ): Don Sanche e Estrelle não fazem mais que trocar juras de amor, provocando uma súbita, longa suspensão da ação dramática. O público clássico, habituado a progressões em moto contínuo, a cenas que conduzem irreparavelmente ao desfecho, sentiu-se aborrecido e protestou. O Globe respondeu: "depuis quand cette impatience d'arriver au but, qui tourmente incessamment le public français au théâtre, dutelle être regardée comme un don heureux de la nature pour sentir la beauté dans les arts?"

\footnotetext{
42 "Não era mais Talma", ou seja, ele próprio.

${ }^{43}$ A tradução do trecho completo é a seguinte: "essa peça que o senhor Lebrun decora com o título de tragédia, mas que não pertence realmente a nenhum gênero conhecido, é traduzida e imitada de don Candido Maria Trigueras, autor de Don Sanche de las Roclas [sic], e, por certos detalhes, de uma comédia de Lope de Vega intitulada La Perle de Séville [sic]".

44 "Nossos adversários".

45 "O dia está em seu declínio; a lua acaba de se levantar; os suaves perfumes da noite embalsamam o ar, e à distância se fazem escutar os sons agonizantes da barulhenta alegria das festas; eles chegam à orelha dos dois amantes, e é então que começa entre eles uma cena sem exemplo em nosso teatro, e de um charme verdadeiramente inexprimível".

46 "Não é ela [a cena] como um primeiro e estranho esboço da cena entre dona Sol e Hernani?".

${ }^{47}$ Não se pode deixar de notar, ademais, na postura de Bustos contra a entrada da corte em Sevilha e a favor da liberdade local, uma reminiscência de duas peças alemãs: o Götz von Berlichingen (1773) de Goethe e o Wilhelm Tell (1804) de Schiller.
} 
(THÉÂTRE-FRANÇAIS, 1825b, p. 379) ${ }^{48}$.

Censura-se ainda a "malveillance visible" (THÉÂTRE-FRANÇAIS, 1825a, p. 374) ${ }^{49}$ e os "mécontentements calculés" (THÉÂTRE-FRANÇAIS, 1825a, p. 375) 50 de uma parte da plateia que, desde o terceiro, mas principalmente durante o quinto ato, teria se empenhado em atrapalhar a encenação, fazendo troça dos momentos mais comoventes. Essa reação desconcertante, rematada a tragédia, fez com que o público estourasse numa peleja de aplausos e assovios:

...cette tragédie, pour laquelle tout faisait espérer d'abord le plus beau des succès, un succès d'émotions et de larmes, s'est dénouée parmi un bruyant combat d'applaudissements, et, il faut le dire, de sifflets. Les premiers ont triomphé toutefois, et le nom de M. Lebrun, auteur de Marie Stuart, a été proclamé. (THÉÂTRE-FRANÇAIS, 1825a, p. 375) ${ }^{51}$

Aqui a "escarmouche avant Hernani" de que falava Gros (1924), e que bem demonstra uma plateia dividida, mas menos fornida do apoio de um regimento romântico, como na première do Hernani - o que, diga-se de passagem, garantiu seu triunfo. A tragédia, abandonada a si, foi logo a pique. O Globe, avaliando que o Cid d'Andalousie, apesar das inovações, preservava muitas características da tragédia habitual (como, aliás, o

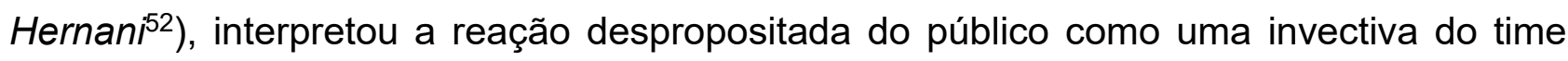
rival:

Les vengeurs des théories dites classiques se sont peu attaqués aux innovations, et ont réuni tous leurs efforts contre ce qui ne devait pas les choquer, contre ce qu'ils eussent dû même applaudir, s'ils se fussent inquiétés d'être conséquents : voilà leur bon sens, voilà leur justice. (THÉÂTRE-FRANÇAIS, 1825b, p. 378) $)^{53}$

A essa altura, certamente a fim de salientar a má vontade dos defensores do classicismo, o Globe parece recuar: o Cid de Lebrun não é mais tão inovador que valesse as severas reprimendas dos jornalistas. Há novidade, mas na medida em que a nova escola a exige, sem exageros. À "grande et capitale objection faite à cet ouvrage", que é

celle de confondre tous les tons et tous les genres, de placer l'intérêt dans

\footnotetext{
48 "Desde quando essa impaciência de chegar ao fim, que tormenta incessantemente o público francês no teatro, deve ela ser vista como um dom feliz da natureza para sentir a beleza nas artes?".

49 "Malevolência visível".

50 "Descontentamentos calculados".

51 "Essa tragédia, na qual tudo fazia esperar, a princípio, o mais belo dos sucessos, um sucesso de emoções e de lágrimas, se desenrolou em meio a um barulhento combate de aplausos e, é preciso dizê-lo, de assovios. Os primeiros, contudo, triunfaram, e o nome do senhor Lebrun, autor de Marie Stuart, foi proclamado".

52 "Écrite en cinq actes et en vers", diz Roxane Martin (2008, n. p.), "la pièce [Hernani] respecte la forme tragique et propose une utilisation de la musique qui, bien qu'audacieuse, ne déroge pas aux usages de la Comédie-Française" - em minha tradução: "escrita em cinco atos e em versos, a peça respeita a forma trágica e propõe uma utilização da música que, ainda que audaciosa, não derroga os costumes da ComédieFrançaise".

53 "Os vingadores das teorias ditas clássicas são pouco dados a inovações e reuniram todos os esforços contra aquilo que não devia chocá-los, contra aquilo que eles deveriam mesmo aplaudir, se eles se preocupassem em ser consequentes: aí está o seu bom senso, aí sua justiça".
} 
une sorte de fantasmagorie dramatique qui fait passer sous les yeux du spectateur l'assemblage indistinct de mille objets divers, [...] tandis que nos grands maîtres soutiennent si habilement pendant cinq actes le développement d'une seule et même action (THÉÂTRE-FRANÇAIS, 1825b, p. 379$)^{54}$,

o Globe responde que "la pièce de $M$. Lebrun est tout aussi simplement construite que beaucoup de nos ouvrages dits classiques" 55 e não supera em muito a variedade de objetos que se encontra nas tragédias de Corneille ou Racine - "como são injustos os clássicos!" é o que querem dizer. Depois do recuo, entanto, um novo assalto:

Nous pourrions aborder plus franchement encore la question, et convenir que cela même que l'on reproche à l'auteur du nouveau Cid est ce que nous appelons de tous nos vœux; que l'art tragique, expirant aujourd'hui en France parmi les entraves de l'étiquette et les langueurs d'un ennui de convention, reprendra vie alors seulement qu'il ira puiser à la source de la réalité, et reproduira changeant et complexe, comme il est, le tableau de l'existence humaine... (THÊÂTRE-FRANÇAIS, 1825b, p. 380) (T6 $^{5}$

Estamos diante dos mesmos argumentos que Staël e Guizot desenvolviam para explicar o efeito de realidade e profundidade sentimental na mistura dos opostos empregada por Shakespeare. A primeira:

On remarque dans Shakespeare, et quelquefois aussi dans les écrivains allemands, une façon hardie et singulière de montrer dans la tragédie même le côté ridicule de la vie humaine; et lorsqu'on sait opposer à cette impression la puissance du pathétique, l'effet total de la pièce en devient plus grand. La scène française est la seule où les limites des deux genres, du comique et du tragique, soient fortement prononcées; partout ailleurs le talent comme le sort se sert de la gaieté pour acérer la douleur. (STAËL-HOLSTEIN, 1813, p. 270$)^{57}$

E Guizot:

Comment la tragédie et la comédie se seraient-elles présentées et formées isolément dans la littérature, lorsque, dans la réalité, elles étaient sans cesse en contact, enlacées dans les mêmes faits, entremêlées dans les mêmes

\footnotetext{
54 Tradução do trecho completo: "restaria combater a grande e capital objeção feita a esse trabalho, aquela de confundir todos os tons e todos os gêneros, de colocar o interesse em um tipo de fantasmagoria dramática que faz passar sob os olhos do espectador o conjunto indistinto de mil objetos diversos, [...] enquanto que nossos grandes mestres sustêm tão habilmente durante cinco atos o desenvolvimento de uma só e mesma ação".

55 "A peça do senhor Lebrun é tão simplesmente construída quanto muitas das obras ditas clássicas".

56 "Nós poderíamos abordar mais francamente ainda a questão e convir que aquilo mesmo que se censura ao autor do novo Cid é aquilo que nós chamamos com todos os nossos votos; que a arte trágica, hoje expirando na França entre os entraves da etiqueta e os langores de um tédio de convenção, recuperará a vida apenas quando ela buscar na fonte da realidade e reproduzir cambiante e complexa, como ele é, o quadro da existência humana".

57 "Nota-se em Shakespeare, e às vezes também nos escritores alemães, uma maneira ousada e singular de mostrar na tragédia mesmo o lado ridículo da vida humana, e quando se sabe opor a essa impressão a potência do patético, o efeito total da peça se torna maior. A cena francesa é a única onde os limites dos dois gêneros, do cômico e do trágico, são fortemente pronunciados. Em todos os outros lugares, o talento se serve da felicidade para aguçar a dor".
} 
actions, si bien qu'à peine quelquefois apercevait-on, de l'une à l'autre, le moment du passage ? (GUIZOT, 1821, p. Ixx) ${ }^{58}$

Por fim, resta aos advogados do romantismo que avaliem a linguagem escolhida pelo poeta. "A en croire le plus grand nombre de nos journalistes, rien de plus commun, de plus lâche, de plus prosaïque que la diction du Cid d'Andalousie" (THÉÂTRE-FRANÇAIS, 1825b, p. 380$)^{59}$. O Globe não nega essa acusação ${ }^{60}$. Os versos de Lebrun, realmente, são simples e diretos, pouco perifrásticos; eles antecipam, de certa forma, uma das orientações mais significativas do prefácio de Cromwell: "malheur au poète si son vers fait la petite bouche!" (HUGO, 1880, p. 56) ${ }^{61}$, pois ele tudo deve conter, mesmo as vulgaridades mais cotidianas ${ }^{62}$. $\mathrm{O}$ artigo do Globe acolhe essa linguagem com entusiasmo:

Les vers de comédie abondent dans son ouvrage [o Cid de Lebrun] ; il aime à appeler les choses par leur nom, et fuit l'ambition des périphrases. Le mouvement enfin est plutôt en dedans qu'au dehors de la diction; et plus les sentiments sont élevés, plus ils se produisent avec simplicité et franchise. Voilà ce qui a été chez lui le principal objet du blâme, voilà ce que nous y louons. (THÉÂTRE-FRANÇAIS, 1825b, p. 380) ${ }^{63}$

Os leitores clássicos reagiram com escândalo frente à vulgaríssima palavra chambre [quarto], empregada por Lebrun em um dos versos do Cid; o Globe se viu na obrigação de lembrá-los, ainda uma vez expondo a má vontade com que receberam a nova tragédia, que Racine a utiliza em Athalie. É verdade, ademais, que o artigo reconhece vícios e negligências no estilo do Cid d'Andalousie, impróprios até mesmo na prosa: ele é repleto de expressões que não pertencem mais à linguagem familiar do que ao "beau langage"; ele emprega muitos neologismos e volta frequentemente sobre as mesmas palavras. As imperfeições, contudo, não valem o desprezo que a tragédia recebeu, e o autor do artigo chega ao fim incitando o leitor "sans préjugé" a observar a fisionomia "réellement humaine" das personagens, a vivacidade dos diálogos, a expressão fiel dos modos históricos, o patético simples e natural das situações etc. etc.

\footnotetext{
58 "Como a tragédia e a comédia seriam apresentadas e formadas isoladamente na literatura, quando, na realidade, elas estavam sem cessar em contato, enlaçadas nos mesmos fatos, misturadas nas mesmas ações, tão bem que apenas com dificuldade, às vezes, se percebia o momento de passagem de um ao outro?".

59 "A crer no maior número de nossos jornalistas, nada de mais comum, de mais solto, de mais prosaico que a dicção do Cid d'Andalousie".

60 Nem o autor: "la plus grande innovation de ma tragédie était dans le style. J'avais cherché à le faire descendre cette fois au ton le plus simple et le plus familier que pût supporter le drame sérieux" (LEBRUN, 1844, p. 240). Em minha tradução: "a maior inovação da minha tragédia estava no estilo. Eu havia tentado fazê-la descer, dessa vez, ao tom mais simples e mais familiar que pode suportar o drama sério".

61 "Ai do poeta se diz seu verso à boca pequena".

${ }^{62}$ Essa ideia já havia sido esboçada por Madame de Staël, que julgava ser a pompa dos versos alexandrinos um obstáculo maior à renovação teatral do que a rotina do bom gosto. Veja-se, a respeito, em Staël-Holstein (1813, p. 12).

63 "Os versos de comédia abundam no seu trabalho; ele gosta de chamar as coisas pelo seu nome e foge da ambição das perífrases. O movimento está mais dentro do que fora da dicção, e mais os sentimentos são elevados, mais eles se produzem com simplicidade e franqueza. Eis o que foi o principal motivo de censura em sua obra; eis o que nós nela louvamos".
} 


\section{Ainda algumas tragédias}

A concisão necessária a este texto exige que eu restrinja o argumento a um só exemplo. Convido os leitores interessados, contudo, a se debruçarem sobre outras tragédias histórico-românticas que não puderam ser abarcadas neste artigo, mas servem de contraponto por terem sido publicadas depois do Cromwell. De Casimir Delavigne: Marino Faliero (1829), Louis XI (1833) etc.; de Alexandre Dumas: Charles VII chez ses grands vassaux (1831), Caligula (1838) etc. Meia palavra sobre esses autores:

Casimir Delavigne foi considerado exemplo de moderação entre classicismo e romantismo no Brasil e em Portugal, dois países onde os primeiros representantes do romantismo se opuseram enfaticamente à difusão desregrada de dramas considerados imorais. Na França, por outro lado, onde o povo se acostumou rapidamente às fortes emoções do bulevar, Delavigne foi sempre visto pelos historiadores como um romântico superficial. Em todo caso, ele acompanhou o movimento do tempo (não apenas no teatro) e não se pode com justiça negar-Ihe uma posição no hall do romantismo francês ${ }^{64}$. Em 1829, publica Marino Faliero (tragédia que, aliás, leva o mesmo título da historical tragedy de Byron, publicada em 1821) junto de um prefácio em que deixa suspensa a sua filiação a qualquer escola exclusiva, mas a crítica jornalística o define claramente como um dramaturgo romântico - o Figaro de 7 de abril de 1829, por exemplo, se refere a Marino Faliero como "mélodrame en 5 tableaux et en vers, avec musique de Rossini", e assegura que a peça dará ocasião para uma comemoração romântica, já que representa um "coup mortel porté au génie antique" (THÉÂTRE DE LA PORTE SAINT-MARTIN, 1829, p. 1)65. Em 1833, Delavigne publica Louis XI, peça encenada como tragédia em 1832 e publicada da mesma forma, ainda que fosse "presque entièrement un drame romantique" (SOURIAU, 1885 , p. 279), quer dizer, "quase inteiramente um drama romântico"66; também em 1833, Delavigne publica Les enfants d'Édouard, peça já encenada como tragédia em 1832, e que Maurice Souriau (1885) preferiu caracterizar como um drama:

C. Delavigne franchit le dernier pas dans les Enfants d'Édouard [...]; car, si

\footnotetext{
64 Maurice Souriau escreve que Delavigne se aproximou do drama romântico apesar de nunca ter participado do círculo intelectual de Victor Hugo, como se este tivesse o monopólio do movimento francês: "Casimir Delavigne n'a jamais appartenu au Cénacle, et pourtant nous pouvons noter dans son théâtre un acheminement progressif vers le drame" (SOURIAU, 1885, p. 277) - em minha tradução: "Casimir Delavigne nunca pertenceu ao Cénacle, e contudo nós podemos notar um encaminhamento progressivo em direção ao drama no seu teatro".

65 Tradução do trecho completo: "este melodrama em 5 quadros e em versos [Marino Faliero], com música de Rossini, é, assegura-se, um grande feito e um golpe mortal contra o gênio antigo; será para os românticos, essa gente celerada, uma bela ocasião para dançar uma ciranda [...] ao redor do prédio do Constitutionnel, na porta do qual a defunta Melpômene, rodeada por velas, esperará da amizade do senhor Baour [Pierre Baour-Lormian] a graça de uma última gota de água benta".

66 É notável que Maurice Souriau não fale uma só vez em tragédia romântica no livro De la convention dans la tragédie classique et dans le drame romantique (1885), precisamente porque sua intenção é produzir uma narrativa que justifique a cisão completa entre drama e tragédia. É claro que um poeta do meio-termo como Casimir Delavigne e teóricos pré-hugoanos como Schlegel, Staël, Manzoni et alii, evidentemente moderados, não se prestam à escrita dessa narrativa e, por isso mesmo, são frequentemente postos à margem do que se entende por movimento romântico.
} 
l'on peut dans ce drame trouver encore un songe de tragédie, tout la scène du début est gracieuse et vraie, et l'entrevue de Tyrrel et de Glocester ressemble d'une façon frappante à celle de don Salluste et de César. (SOURIAU, 1885, p. 280) ${ }^{67}$

O caso de Dumas é interessante por outros motivos. Incontestavelmente romântico, ele defendia a liberdade total na criação dramática: "je n'admets pas, en littérature, de système; je ne suis pas d'école; je n'arbore pas de bannière. Amuser et intéresser, voilà les seules règles, je ne veux pas dire que je suive, mais que j'admette" (DUMAS, 1884, p. 8) ${ }^{68}$. A contraparte inesperada desse programa é que ele também prevê a liberdade de compor tragédias clássicas. No prefácio de Charles VII, essa peça em versos, cinco atos, atenta às regras aristotélicas e encenada no Odéon, Dumas declara:

Je cherchais la matière d'un drame ; [...] il se présenta à mon esprit sous une forme classique : je l'adoptai.

Le théâtre est, avant tout, chose de fantaisie ; je ne comprends donc pas qu'on l'emprisonne dans un système. Un même sujet se présentera sous vingt aspects divers à vingt imaginations différentes. Tracez des règles uniformes, forcez ces imaginations de les suivre, et il y a cent à parier contre un que vous aurez dix-neuf mauvais ouvrages; laissez chacun prendre son sujet à sa guise, le tailler à sa fantaisie; accordez liberté entière à tous, depuis les douze heures de Boileau jusqu'aux trente ans de Shakespeare, depuis le vers libre de Jodelle jusqu'à l'alexandrin de Racine, depuis les trilogies de Beaumarchais jusqu'aux proverbes de Théodore Leclercq: et alors chaque individu flairera ce qui convient le mieux à son organisation, amassera ses matériaux, bâtira son monde à part, soufflera dessus pour lui donner la vie, et viendra, au jour dit, avec un résultat sinon complet, du moins original; sinon remarquable, du moins individuel. (DUMAS, 1884, p. 228) ${ }^{69}$

Isso quer dizer que as tragédias de Dumas abrem mão da riqueza visual e de todo o aparato cenográfico que ele aprendeu a manusear no bulevar? É evidente que não.

\footnotetext{
67 "Casimir Delavigne dá o último passo [em direção ao drama romântico] em Les enfants d'Édouard [...], pois se ainda podemos encontrar um sonho de tragédia nesse drama, toda a cena inicial é graciosa e verdadeira, e a entrevista de Tyrrel e Glocester se assemelha de maneira impressionante àquela de don Salluste e César". Note-se como essa análise revela duas premissas subjacentes ao argumento de Souriau: i) que o verdadeiro drama romântico não tem "sonhos de tragédia", o que é contrário à própria mistura de gêneros, base do drama; ii) que o modelo do teatro romântico é Victor Hugo, ainda que aplicado retroativamente (don Salluste e César são personagens do Ruy Blas, drama encenado em 1838).

68 "Eu não admito sistema em literatura; eu não sou de escola; eu não levanto bandeira. Divertir e interessar, eis as únicas regras, não quero dizer que eu sigo, mas que eu admito".

69 "Eu buscava o assunto de um drama; [...] ele se presentou a meu espírito sob uma forma clássica: eu a adotei.

O teatro é, antes de mais nada, uma coisa de fantasia. Eu não compreendo que the aprisionem em um sistema. Um mesmo assunto se apresentará sob vinte aspectos diversos a vinte imaginações diferentes. Trace regras uniformes, force essas imaginações a segui-las e há cem para apostar contra um que você terá dezenove trabalhos ruins. Deixe cada um tomar seu assunto como quiser, o talhar segundo a sua fantasia, conceda liberdade inteira a todos, das doze horas de Boileau aos trinta anos de Shakespeare, dos versos livres de Jodelle ao alexandrino de Racine, das trilogias de Beaumarchais aos provérbios de Théodore Leclercq, e então cada indivíduo farejará o que convém melhor à sua organização, acumulará seus materiais, construirá seu mundo à parte, soprará sobre ele para lhe dar vida e virá, no dia marcado, com um resultado senão completo, pelo menos original; senão notável, ao menos individual".
} 
Caligula, por exemplo, tragédia ${ }^{70}$ com a qual Dumas desejava revelar as feições cômicas, amorosas e familiares da sisuda antiguidade, se aproxima não só do drama, como flerta com o melodrama. Daí o tom realista e pitoresco dessa tragédia, muito ao gosto da época:

Ce souci de la précision dans l'infiniment petit est tel que dans Caligula nous voyons les jeunes Romains lire les Actes Diurnaux dans la boutique d'un barbier, ou plutôt d'un tondeur, on li au-dessus de sa porte: «Bibulus tonsor ", et l'on pourrait même s'étonner qu'on parle français devant une boutique si scrupuleusement latine, ou que Lépidus parle d'aller prendre un bain dans des balnea. (SOURIAU, 1885, p. 231) 71 $^{71}$

Note-se como é viva a descrição do espetáculo dada pelo jornal Le Figaro em 19 de outubro de 1837:

Dans le prologue, on verra une place publique de Rome, d'abord obscure, ensuite éclairée peu à peu par le soleil levant. Les arrestations mystérieuses, les amours nocturnes, les folles orgies se meuvent à l'aise dans la ville endormie. Puis le peuple se lève, la foule bruit dans les rues. [...] Le char de Caligula est traîné par des femmes représentant les heures. On parle même d'un éléphant, éléphant de carton, il est vrai, que deux figurants feront mouvoir [...]. La mise en scène du cinquième acte sera très brillante. II y a un festin antique, avec des lits de pourpre, des danseuses, des chœurs, et tout l'appareil décrit par Pétrone. (CHRONIQUE, 1837, p. 2) ${ }^{72}$

Toda essa pompa faz pensar no bulevar. É inegável que a tragédia, em princípios do século XIX, também encontrava nele uma fonte de inspiração.

"On a dit que cet ouvrage était venu trop tôt", escreve Lebrun em 1844, quando finalmente imprime o Cid d'Andalousie, "aujourd'hui, ne dira-t-on pas qu'il vient trop tard?" (LEBRUN, 1844, p. 248) $)^{73}$. Realmente, diante do quadro geral, não se pode deixar de

70 Parece que houve controvérsia em relação ao gênero, como sugere este artigo publicado em 2 outubro de 1837 pelo Constitutionnel: "le Théâtre-Français a entendu jeudi la lecture de Caligula, tragédie de M. Alexandre Dumas annoncée depuis près de deux ans. [...] Les romantiques disent, par antithèse, que c'est un drame antique, conçu et exécuté dans les formes nouvelles" (CHRONIQUE THÉATRALE, 1837, p. 2). Traduzindo: "o Théâtre-Français ouviu na quinta-feira a leitura de Caligula, tragédia do senhor Alexandre Dumas, anunciada há quase dois anos. [...] Os românticos dizem, por antítese, que ela é um drama antigo, concebido e executado nas novas formas". De fato, há vários artigos que chamam Caligula de drama, e às vezes mesmo de tragédia e drama indistintamente - nessa oscilação se reconhece, mais uma vez, a débil impermeabilidade dos gêneros dramáticos e o vão esforço de alguns adeptos da nova escola para afastá-la de toda herança clássica. A disputa, no entanto, está fora de questão, pois o próprio autor publicou a obra como tragédia em 1838, e foi como uma tentativa de renovar a tragédia que ela foi recebida, para bem ou para mal.

71 "Essa preocupação com a precisão infinitesimal é tal que, em Caligula, nós vemos os jovens romanos lerem as Acta Diurna [espécie de jornal romano] na butique de um barbeiro, ou melhor, de um tosquiador, lê-se em cima da sua porta: 'Bibulus tonsor' [barbeiro Bibulus], e poderíamos mesmo nos surpreender que se fale francês em frente a uma butique tão escrupulosamente latina, ou que Lepidus fale de ir tomar um banho em balnea".

72 "No prólogo, se verá um lugar público de Roma, a princípio obscuro, depois iluminado pouco a pouco pelo sol nascente. As prisões misteriosas, os amores noturnos, as loucas orgias se movem à vontade pela cidade adormecida. Depois o povo se levanta, a multidão faz barulho nas ruas. [...] A carruagem de Calígula é puxada por mulheres representando as horas. Se fala mesmo em um elefante (elefante de papelão, é verdade) que dois figurantes moverão [...]. A mise en scène do quinto ato será muito brilhante. Há um festim antigo com camas púrpuras, dançarinas, coros e todo o aparato descrito por Petrônio".

73 "Disseram que esse trabalho teria vindo muito cedo. Hoje, não se dirá que ele veio muito tarde?". 
pensar que Pierre Lebrun foi prejudicado por um timing infeliz. Não só muitos dramas posteriores ao Cromwell se mostraram tão românticos quanto a sua peça, como alguns dramaturgos se apropriaram de seus métodos e se gabaram dos seus méritos ${ }^{74}$. Fosse Lebrun mais afeiçoado aos poetas do Cénacle ou tivesse o seu Cid encontrado uma plateia cinco anos mais tarde, sua recepção seria diferente, e pode até ser que a tragédia viesse listada nos livros de história como uma obra romântica, à sombra do Hernani.

\section{Considerações finais}

Mostrei, neste trabalho, que a tragédia histórica (ou romântica) atende às expectativas dos intelectuais que se identificavam com o romantismo nas primeiras décadas do século XIX (Staël, Manzoni, Schlegel etc.); que ela antecipa várias características do drama romântico (mistura de gêneros, desrespeito às unidades clássicas, preocupação histórica, enriquecimento de decoração e figurino, complexificação da trama etc.) e, enfim, que ela mantém um evidente comércio com o drama e o melodrama depois de 1827, não raro com eles dividindo os mesmos palcos e atores. Que alternativa nos resta, diante desse quadro, senão concordar com Roxane Martin?

Au regard de la diversité des productions dramatiques du XIXe siècle, il est impossible de restreindre le théâtre romantique au seul exemple du drame. Le théâtre du XIXe siècle met en jeu un réseau complexe de genres aux contours perméables, et paraît, de ce fait, ne pouvoir se satisfaire des périmètres génériques que lui octroie généralement la critique littéraire. (MARTIN, 2004, p. $267-268)^{75}$

De fato, o teatro romântico não se identifica com o drama; sua teoria não se restringe às doutrinas de Victor Hugo.

Mencionei os nomes de José Veríssimo, Alfredo Bosi e Antonio Candido. Todos esses intelectuais tendem a associar o teatro romântico (histórico, sem unidades de tempo e lugar etc.) exclusivamente com o drama hugoano, promovendo não só a aclimatação de ideias equivocadas, como incentivando o emprego de padrões previamente distorcidos (como mostrei neste trabalho) e que, aplicados à cena brasileira, são causa de alguns julgamentos improdutivos. Este trabalho pode ser lido, assim, como ponto de partida para uma reflexão sobre a cena romântica por aqui. Se levarmos em conta, além das teorias próprias aos

\footnotetext{
74 Um exemplo: no prefácio de Henri III et sa cour (1829), Dumas agradece pela atuação de Mademoiselle Mars (que, vimos, foi a Estrelle do Cid de Lebrun), vangloriando-se de nela haver "deviné des qualités tragiques, contestées jusqu'aujourd'hui, et qui n'avaient besoin, pour se développer avec tant d'éclat, que de rencontrer une tragédie moderne" (DUMAS, 1829, p. viii), quer dizer, de ter "adivinhado qualidades trágicas, contestadas até hoje, e que não precisavam, para se desenvolver com tanto brilho, senão de encontrar uma tragédia moderna". É esse o mesmo Dumas que, nas suas memórias, descreve o Cid d'Andalousie como uma peça tediosa e Lebrun como um dramaturgo medíocre - veja-se o livro de Dumas, Mes mémoires (1867), p. 155-157, mencionado na bibliografia deste trabalho.

75 "Dada a diversidade das produções dramáticas do século XIX, é impossível restringir o teatro romântico ao único exemplo do drama. O teatro do século XIX põe em jogo uma rede complexa de gêneros com contornos permeáveis e, portanto, parece incapaz de se contentar com os perímetros genéricos geralmente concedidos pela crítica literária".
} 
nossos primeiros dramaturgos, as condições especiais de produção nacional (incentivo imperial, predomínio da filosofia eclética, uma tradição poética própria, limitações materiais etc., etc.), teremos uma ideia mais clara de que o teatro romântico brasileiro não poderia ter sido aquilo que foi na França. Ele produziu precisamente aquilo que, dentro das suas condições particulares, foi capaz de produzir; resta a nós estudá-lo de acordo.

\section{Referências}

BOSI, Alfredo. História concisa da literatura brasileira. São Paulo: Cultrix, 1975.

BRUNETIĖRE, Ferdinand. Victor Hugo. Paris: Librairie Hachette et cie., 1902. t. 2.

C. Théâtre-Français. Journal des débats politiques et littéraires. Paris, p. 1-4, 3 mar. 1825a.

C. Théâtre-Français. Journal des débats politiques et littéraires. Paris, p. 1-3, 10 mar. $1825 \mathrm{~b}$.

CH. Théâtre-Français. Gazzete de France, Paris, n. 65, 6 mar. 1825.

CANDIDO, Antonio. Formação da literatura brasileira. Belo Horizonte: Editora Itatiaia, 2000. v. 1.

CHRONIQUE. Figaro. Paris, p. 1-2, 19 out. 1837.

CHRONIQUE THÉATRALE. Le Constitutionnel. Paris, n. 275, p. 2, 2 out. 1837.

CLERICI, Edmondo. /I "Conciliatore": periodico milanese (1818-1819). Pisa: Tipografia Successori FF. Nistri, 1903.

CONSTANT, Benjamin. Du Théâtre français et du Théâtre étranger. Mercure de France. Paris, p. 484-490, 13 dez. 1817.

DU DRAME HISTORIQUE ET DE LA TRAGÉDIE ROMANTIQUE. Le Figaro. Paris, n. 210, p. 433-434, 16 out. 1827.

DUMAS, Alexandre. Henri IIl et sa cour. Paris: Vezard et Cie.; Le Normant Père, 1829.

DUMAS, Alexandre. Mes mémoires. Paris: Michel Lévy Frères, 1867. v. 4.

DUMAS, Alexandre. Théâtre complet de Alexandre Dumas. Paris: Calmann Lévy éditeur, 1884. v. 2.

FAURIEL, Claude. Préface du traducteur. In: MANZONI, Alessandro. Le comte de Carmagnola et Adelghis. Paris: Bossange Frères, 1834, p. I-XX.

FERRARI, Luigi. Del "Caffè": periodico milanese del secolo XVIII. Pisa: Tipografia Successori Fratelli Nistri, 1900.

GROS, Etienne. Le Cid après Corneille. Revue d'Histoire Littéraire de la France. Paris: Librairie Armand Colin, 1924, p. 1-45. 
GUIZOT, François. Vie de Shakespeare. In: SHAKESPEARE, William. CEuvres complètes de Shakespeare. Paris: Chez l'Advocat, 1821, p. iii-clii.

HUGO, Victor. OEuvres complètes de Victor Hugo: drame. Paris: Édition Hetzel-Quantin; Librairie A. Houssiaux, 1880. v. 1.

LANSON, Gustave. Esquisse d'une histoire de la tragédie française. Nova lorque: Columbia University Press, 1920.

LANSON, Gustave. Manuel bibliographique de la littérature française moderne (1500-1900). Paris: Librairie Hachette, 1911.

LEBRUN, Pierre. CEuvres complètes de Pierre Lebrun. Paris: Perrotin, libraire-éditeur, 1844. t. 1.

MANZONI, Alessandro. Le comte de Carmagnola et Adelghis. Paris: Bossange Frères, 1834.

MANZONI, Alessandro. Opere varie. Milão: Fratelli Rechiedei editori, 1881.

MANZONI, Alessandro. Tragedie di Alessandro Manzoni. Pisa: Presso Niccolò Capurro, 1826.

MARSAN, Jules. Le théâtre historique et le romantisme. In: SOCIÉTÉ D'HISTOIRE LITTÉRAIRE DE LA FRANCE (Org.). Revue d'histoire littéraire de la France. Paris: Librairie Armand Colin, 1910, p. 1-33. t. 17.

MARTIN, Roxane. Hernani: un mélodrame? Analyse comparative de la fonction dramatique de la musique de scène dans les dramaturgies mélodramatique et hugolienne. In: ANDREUCCI, Alain (Org.). Méthode! Revue de littératures. Número 14. Vallongues: 2008, p. 217-224.

MARTIN, Roxane. La féerie sur les scènes secondaires du Directoire et du Consulat: Genèse d'un théâtre «romantique»? In: BOURDIN, Philippe; LOUBINOUX, Gérard. La scène bâtarde entre Lumières et romantisme. France: Presses Universitaires Blaise Pascal, 2004, p. 255-268.

O., Du Romantique. Le Globe. Paris, n. 85, p. 423-424., 24 mar. 1825.

R. Théâtre-Français. Journal des débats politiques et littéraires. Paris, p. 1-4, 13 mar. 1820.

SOURIAU, Maurice. De la convention dans la tragédie classique et dans le drame romantique. Paris: Librairie, Hachette et cie., 1885.

STAËL-HOLSTEIN, Anne-Louise Germaine de. De l'Allemagne. Paris: H. Nicolle à la Librairie Stéréotype, 1813. t. 2.

STENDHAL. Correspondance de Stendhal. Paris: Charles Bosse, 1908. t. 2.

STENDHAL. Racine et Shakespeare: études sur le romantisme. Paris: Michel Lévy Frères, 1854. 
STENDHAL. Rome, Naples et Florence. Paris: Librairie ancienne Honoré Champion, 1919. THÉÂTRE DE LA PORTE SAINT-MARTIN. Le Figaro. Paris, n. 97, p. 1-2, 7 abr. 1829.

THÉÂTRE-FRANÇAIS. Le Globe. Paris, n. 76, p. 373-375, 3 mar. 1825a.

THÉÂTRE-FRANÇAIS. Le Globe. Paris, n. 77, p. 378-380, 7 mar. 1825b.

TIEGHEM, Paul Van. Le mouvement romantique. Paris: Librairie Vuibert, 1923.

TIEGHEM, Paul Van. Le romantisme dans la littérature européenne. Paris: Éditions Albin Michel, 1948.

WAILLE, Victor. Le romantisme de Manzoni. Argel: Imprimerie Pierre Fontana \& Compagnie, 1890.

\section{NOTAS DE AUTORIA}

Gabriel Esteves (gabrielesteues@gmail.com) possui graduação em Letras-Língua Portuguesa (2017) e mestrado em Literatura (2020) pela Universidade Federal de Santa Catarina (UFSC). Hoje é doutorando (bolsista CNPq) do Programa de Pós-Graduação em Literatura da mesma instituição, integra o Núcleo de Pesquisas em Informática, Literatura e Linguística (NuPILL) e edita a revista Mafuá de literatura em meio digital.

Agradecimentos

Não se aplica.

\section{Como citar esse artigo de acordo com as normas da ABNT}

ESTEVES, Gabriel. Tragédia histórica e drama romântico. Anuário de Literatura, Florianópolis, v. 26, p. 0122, 2021.

\section{Contribuição de autoria}

Não se aplica.

\section{Financiamento}

Este trabalho foi realizado com apoio do CNPq, Conselho Nacional de Desenvolvimento Científico e Tecnológico - Brasil.

\section{Consentimento de uso de imagem \\ Não se aplica.}

\section{Aprovação de comitê de ética em pesquisa}

Não se aplica.

\section{Conflito de interesses}

Não se aplica.

\section{Licença de uso}

Os/as autores/as cedem à Revista Anuário de Literatura os direitos exclusivos de primeira publicação, com o trabalho simultaneamente licenciado sob a Licença Creative Commons Attribution (CC BY) 4.0 International. Estra licença permite que terceiros remixem, adaptem e criem a partir do trabalho publicado, atribuindo 0 devido crédito de autoria e publicação inicial neste periódico. Os autores têm autorização para assumir contratos adicionais separadamente, para distribuição não exclusiva da versão do trabalho publicada neste periódico (ex.: publicar em repositório institucional, em site pessoal, publicar uma tradução, ou como capítulo de livro), com reconhecimento de autoria e publicação inicial neste periódico. 


\section{Publisher}

Universidade Federal de Santa Catarina. Programa de Pós-graduação em Literatura. Publicação no Portal de Periódicos UFSC. As ideias expressadas neste artigo são de responsabilidade de seus/suas autores/as, não representando, necessariamente, a opinião dos/as editores/as ou da universidade.

\section{Histórico}

Recebido em: 26/10/2020

Aprovado em: 04/06/2021

Publicado em: 31/08/2021 